\title{
SIMILAR MENTALITY AND PERCEPTION IN THE CONTEXT OF CONTEMPORARY UKRAINE-POLAND RELATIONS
}

\section{Strilchuk L. V., Dobrzhanskiy O. V.}

\section{INTRODUCTION}

To date, Ukraine-Poland relations are recognized as being a topic of paramount importance in both print and electronic media; it has become a matter of special interest to ordinary citizenry in both Poland and Ukraine. In addition, it is quite justifiable, because since the late 90s of the twentieth century the Republic of Poland, bordering on Ukraine, has become its reliable strategic partner. Remarkable features of the established Ukraine-Poland relations are developing mutually beneficial economic cooperation, building effective political momentum, having geographical proximity, cultural and language similarities, as well as the presence of a large Ukrainian national minority in Poland and the Polish one in Ukraine respectively. Thus, a growing body of evidence speaks for Ukraine-Poland relations, providing a great boost to their ongoing political confidence-building narrative as an indispensable part of crossborder cooperation strategies for their sustainable development. However, it is now well established that sharing common pools of memories and historical past can impair interstate coherence and empathy.

Consequently, a challenging problem, which arises in this domain, is an established negative and adverse stereotype and psychological make-up of a Ukrainian in the Republic of Poland and a Pole in Ukraine, which in its turn becomes a powerful tool of influencing interethnic relations. In a broader perspective, two-country's different perceptions of their historical trauma serves as a litmus test determining the tone and tenor of bilateral rapprochement. On the transboundary level, the pragmatic search for joint solutions to common local problems "how to 
integrate actors representing different sectors (public, private, societal) and cultures into existing patterns and structures of cooperation, how to create and manage inter-sectoral synergies in a cross-border perspective ${ }^{1}$ is required.

Noteworthy, the peculiarities of mentality mapping and the moral landscape of two nations immediately influence different interpretations of the shared historical memory and the experience of interaction between the two nations in the neighboring countries. Accordingly, the present study extends on mentality-focused approach to evolution of socio-historical stereotypes as well as the interrelationship and conflictsolving strategy in terms of historical memory of neighboring peoples. Furthermore, to embrace and evaluate state-of-the-art of the UkrainePoland interethnic and interstate relations, the given study is the key contribution to solving disputes over the interpretation of their shared historical memory.

\section{Genetic and cultural traits of Poles and Ukrainians' mentality}

Research suggests that two neighboring nations, Poles and Ukrainians, have been sharing their 700-year of the neighborhood history, which resonates loudly through the centuries; throughout the period the two countries experienced both times of good neighborliness and misunderstandings, open hostility and cleavages. It is obvious that both Ukrainians and Polish mutually influenced each other across the development of their relations, undergoing twists and turns. The processes of living in border areas, and, consequently, developing economic, cultural and political contacts have formed a definite rapport and attitude to the neighboring people.

For a long time, both peoples were incorporated into the same territory powers: the First and Second Commonwealth (Rzeczpospolita),

1 Beck, J. Pradier, E. 2011: Governance in der transnationalen Regionalpolitik: Bestandsaufnahme und Perspektiven der Kooperationsbeziehungen in grenzüberschreitenden Verflechtungsräumen, in: Joachim Beck / Birte Wassenberg (Hrsg), Grenzüberschreitende Zusammenarbeit erforschen und leben (Band 2): Governance in Deutschen Grenzregionen Stuttgart (Steiner), S. 107-135. 
the Austro-Hungarian and Russian empires. Ukrainians and Poles suffered a brutal interethnic confrontation during the Second World War, experienced the construction of socialism and terror of totalitarianism, the collapse of the communist system, as well as elaborating a new model of post-socialist development ${ }^{2}$. All these shared experiences and historical memories united and at the same time divided Ukrainians and Poles. The common historical legacy, but own national historical memory has given rise to many socio-historical stereotypes and myths, which have strongly influenced and continue to influence the national mentality of Poles and Ukrainians and their bilateral relations. The current stage of the Ukrainian and Polish communities' development has much in common, since at the turn of the twentieth and the twenty-first centuries both nations experienced a kind of civilizational explosion, which gave nations a chance to restore their sovereignty and direct their historical development towards independence and democracy ${ }^{3}$.

It should be stated that for humanity scientists the problem of a holistic analysis of interstate Polish-Ukrainian' relations is difficult to handle without a clear understanding of the Polish and Ukrainian nations' conscious awareness and perception, because they significantly affect the interaction style, the applied decision rules, and ultimately the efficiency of cross-border problem-solving strategy.

Therefore, our focus revolves around the essential characteristics of similar mentality and perception of contemporary Ukraine-Poland relations. Furthermore, the problems of mentality and mind setting have attracted much attention in the field of modern humanities studies, which pivotal focus is a holistic system of knowledge about human society, culture, environment and history.

${ }^{2}$ Стрільчук Л. Історична пам'ять українців та поляків: пошук шляхів примирення чи привід до конфлікту? Історичні та політологічні дослідження. Науковий журнал. Спеціальний випуск: доповіді на міжнародній науково-практичній конферениії «Трансформачї історичної пам'яті». Вінниця, 2018. С. 177.

${ }^{3}$ Михальченко Н. Великий цивилизационный взрыв на рубеже XX - XXI векав. К.: Парламентское издательство, 2016. С. 3-5. 
Mentality as a way of thinking and mind setting is increasingly becoming a vital factor in investigating its historically rooted consciousness and behavior, lifestyle and values, traditions and customs, cultivated and fostered in the course of generations' history. Taking into consideration a common humanities and social sciences research focus on scientific approach to understanding essential characteristics of mentality and mindset of the Ukrainian and Polish civilizations, only a few humanities studies have shown mentality continuous cultural intermingling, moral values, history and state-of-the-art reality through the prism of civilizational interpretation the historical process ${ }^{4}$.

Mentality is the psychological make-up of each individual and each nation, each society (in our case study - Polish and Ukrainian). Mentality is integral-cultural-spiritual and ethno-psychological features of the nation, a manifestation of the soul, a characteristic of the nation biography and civilization. A collated model of mentality harmoniously blends such components as emotional-behavioral, authoritative, cognitive, perceptional, and communicative etc. They are formed historically in the process of ethno-genesis, under the influence of sociocultural environment and enable to enrich and be passed on through a form of genetic memory from generation to generation, are manifested in all forms of human activity, in its morals, behavior, consciousness, culture, customs ${ }^{5}$, etc. The long life of Ukrainians in foreign territories, frequent historical disputes between Ukrainians and Poles over neighboring territories, interethnic conflicts on the same border, and the fact that Poles and Ukrainians have preserved their selfhood and uniqueness, their ethnic identity, their mentality and mindset, language and culture, feeling the part of 'other' nation ${ }^{6}$, are the essential characteristics of the mentality. The authors of the present study use a an approach to researching a problem through; and develop on the key concept of the Ukrainian and Polish mentality, determined by

\footnotetext{
${ }^{4}$ Калакура Я. Ментальний вимір української цивілізації. Київ: Генеза. 2017. С. 5.

${ }_{6}^{5}$ Рафальський О. Україна як цивілізаційний феномен. К.: Бланк-Прес, 2010. С. 56.

${ }^{6}$ Горєлов М., Моця О., Рафальський О. Українська етнічна нація. К.: Екопродакшин, 2012. С. 92.
} 
M. Popovych, as a deep and relatively stable set of essential characteristics of collective and individual consciousness of Ukrainians/Poles. This concept determines a national character, traditions, social psychology, cultivated cultural and spiritual values and their own vision of the world ${ }^{7}$.

Mentality, like civilization, is inseparable from the immersion of people in the socio-cultural environment (milieu of its origin, shaping and establishing). The historical legacy, mostly negative, affecting the Polish and Ukrainian mentality was mainly reasoned by frequent interethnic conflicts, long periods of statelessness, being under foreign rule (for example, the Russian and Austro-Hungarian empires, the German occupation regime during World War II), from numerous wars and revolutionary upheavals, migration and assimilation processes ${ }^{8}$.

We present a few, in our opinion, the most significant mental stereotypes, domineering reciprocal labelling in both modern Polish and Ukrainian societies, which are the archetypal of the retransmission of history to the mentality of Ukrainians and Poles. Firstly and in particular, in Poland the negative stereotype of Ukrainians was fostered by sharing historical memories about Khmelnytsky Uprising and Haydamachchyna, as well as instilled by the relatively recent events of World War II, and the events in Volhynia in the mid-1940s of the twentieth century'. Additionally, in the western Ukraine, the Polish neighbor figure dredges up the oppression of Ukrainians during the Second Polish-Lithuanian Commonwealth, when 'Kresy Wschodnie' closed Ukrainian schools, cultural and educational institutions and destroyed Orthodox churches. In addition, the policy of pacification pursued by the Polish government in the 1930s, not only undermined credibility to the Polish government, but set on edge interethnic enmity between the indigenous ethnic group - the

${ }^{7}$ Попович М. Українська національна ментальність. Проблеми теорї ментальності. Відп.ред. М.В. Попович. К.: Наукова думка, 2006. С. 232-240.

${ }^{8}$ Калакура Я. Ментальний вимір української цивілізації. Київ: Генеза. 2017. С. 8.

${ }^{9}$ Стрільчук Л., Стрільчук В. Інституційні складові українсько-польських гуманітарних взаємин і співробітництва. Монографія. Луцьк: Волинські старожитності, 2013. C. 10. 
Ukrainians, and the nation-state - the Poles. The policy of pacification brought sweeping arrests for the Ukrainian population of Volhynia and Galicia, massacres of civilians, and prohibition on the activities of Ukrainian public and cultural institutions and organizations. Another case of vandalism of the Polish government was the destruction of the oldest and most authoritative public and cultural organization 'Prosvita', which defended the national interests of Ukrainians for more than half a century, and functioned in both the Austro-Hungarian and Russian empires. One of the consequences of the pacification policy was the radicalization of the Ukrainian resistance in this area ${ }^{10}$. During the World War II, the Polish underground exterminated the Ukrainian intelligentsia, and at the same time, the operation 'Vistula' became another example of Poland's postwar government attitude towards Ukrainians.

During the period of totalitarianism, the negative stereotypes of both nations intensified due to anti-Polish propaganda in Ukraine and anti-Ukrainian propaganda in Poland respectively, in particular by falsifying and distorting the history. Consequently, in the Polish consciousness, Ukrainians were depicted as 'nationalists' in the most negative sense of the word, and therefore, Ukrainians were seen as the worst enemies of the Poles and the cause of all their misfortunes ${ }^{11 .}$

Regrettably, modern Polish-Ukrainian interethnic relations still need time to rethink and cleanse all negative stereotypes in the mental consciousness of both nations. As previously noted, we consider the main reasons for such antagonism are as followed:

- it is quite difficult to break the biased syndrome ingrained in the mentality of the older generation, this process can take quite a long time, sometimes even some generations might change;

- the established negative stereotype of Ukrainians in Poland is supported by various extremist and nationalist groups and some (certain)

${ }^{10}$ Strilchuk L. The Ukrainian-Polish Confrontation in Volhynia in the Second World War: Historical Memory Transformations. Codrul Cosminului, 2018, Vol. XXIV, No. 1, P. 145-165.

11 Заброварний С. До повного примирення і щирого порозуміння. Політика $i$ час. 1997. № 9. C. 5-11. 
publications in the press. For example, activities of Kresy-oriented organizations in Przemyśl can serve as an excellent example;

-there is a question risen about the good will of the other party's intentions in strengthening collaboration and friendly relations;

- there is a lack of economic and cultural attractiveness of Ukraine for Poles. The Republic of Poland has never seen Ukraine as a financial or technological partner. It is better to say that all of Poland's hopes have been always about Western Ukraine ${ }^{12}$;

- for the Polish society, the vast majority of which is professing Catholicism, Orthodoxy and Greek Catholicism, the religious situation in Ukraine is unclear and incomprehensible, and therefore the religious factor has a strong influence on public consciousness ${ }^{13}$;

- political statements of the Polish political elite throughout 20132016 were mostly focused on the problems of the shared PolishUkrainian historical memories, especially touching the historical emphasis of Polish society on the conflicting moments of the past, in particular, the events of World War II in Volhynia ${ }^{14}$.

Thus, concluding, we potentially provide insights into the mindset of both individuals and cultures, where mentality is a historical pillar of both Polish and Ukrainian civilizations, the contours of which were formed historically within the ethnic territories of Poles and Ukrainians and have a local-border character. Despite heated debates on the essence of the Ukrainian and Polish mentalities, searching for the ways to interact, interpenetrate and establish the historical socio-cultural heritage of Ukrainians and Poles, inseparably linked to European values, is quite

12 Стрільчук Л., Стрільчук В. Інституційні складові українсько-польських гуманітарних взаємин і співробітництва. Монографія. Луцьк: Волинські старожитності, 2013. C. 11.

13 Добржанський О. Еволюція суспільно-історичних стереотипів у свідомості українців та поляків на прикладі опіки над місцями національної пам'яті. Украӥна-Польща: історичне сусідство. Матеріали міжнародної наукової конференції 19-20 травня 2017 p. Вінниця: ТОВ «Нілан-ЛТД», 2017. С. 365-370.

${ }^{14}$ Стрільчук Л. Проблеми історичної пам'яті в сучасних українсько-польських взаєминах. Україна-Польща: історичне сусідство. Матеріали міжнародної наукової конферениії 19-20 травня 2017 р. Вінниця, 2017. С. 375. 
justified, especially in terms of modern European integration processes ${ }^{15}$. Another concluding point is that psychological make-up of the Polish and Ukrainian nations with their strengths and weaknesses has been formed historically. The process of origin and development of mentality, having a long progressive-evolutionary nature, acts as a priority feature of the establishment of cultural, historical and genetic code of civilization, which is influenced by numerous push and pull factors.

\section{Ukraine-Poland relations in the mental dimension of political elites}

Another significant aspect of mental dimension is the fact that Poland-Ukraine inter-ethnic conflicts and the influence of historical memories on the mentality's formation are obvious. In addition, it is important to stress that historical events and facts, crusted in the memory of generations, serve as a kind of framework, perceiving not only their own past and the past of the neighboring people, but also their modern realities. As far as mentality is concerned, mutual support and cooperation during historical collisions and difficulties, or conflicts with neighbors can be an important part to reach the psychological make-up of peoples.

Turning now to another perspective of the study, we should state that Ukrainians have clear knowledge and understanding of the fact that at various times for quite a long period of time ethnic Ukrainian lands used to be the part of the First and Second Polish-Lithuanian Commonwealth, which proves that the Poles deprived Ukrainians of their statehood at least twice. Consequently, the western neighbor is associated in the Ukrainian's mentality with an oppressor, an aggressor, trying to impose their own language, culture, religion, their way of life. On the other hand, mental borders are the ones, which result more difficult to overcome, in the context of modern Polish society' vocalizing their historical borders of Kresy Wschodnie, implying the Ukrainian, Lithuanian and Belarusian lands incorporated. It is now understood, that modern Ukrainian and Polish political elites have not only conveyed the

\footnotetext{
${ }^{15}$ Калакура Я. Ментальний вимір української цивілізації. Київ: Генеза. 2017. С. 9.
} 
sense of their neighbors, but also established traditions of political relations that are with a hint of a certain "psychological" shadow.

Addressing this common challenge and erasing mental borders among both nations and individuals through joint aspirations, inference should be drawn that foreign policy concepts regarding the neighbors of both the Ukrainian and Polish political elites become more relevant over time. Providing an insight into the problem, they acquire new shapes and psychological shadows, while remaining fairly stable. The permanence of foreign policy concepts confirms their mental basis. For this very reason, it was important to use the analysis of the evolution of Poland's foreign policy concepts towards Ukraine while studying the mentalities' similarity of Ukrainians and Poles with an aim to trace the formation of the Polish political elite mentality over the last century. In the light of recent events, it should be stated that today's perception of Ukraine as a state and Ukrainians as neighbors is based on historical traditions and historical experience.

One of the well-accepted statement of the Polish publicist J. Giedroyć demonstrates that two ghosts of Piłsudski and Dmowski embody the modern Republic of Poland ${ }^{16}$. We cannot but agree that modern foreign policy of the Republic of Poland has mostly absorbed the political concepts of J. Piłsudski and R. Dmowski. In particular, two main visions of a new Poland were formed on the wave of Polish state nationalism establishment and are topical until now - Jagiellonian and Piast concepts. In fact, these are the oldest Polish political doctrines, deeply rooted in the prime of the Polish state establishment, the times of greatness and power, and become a model to follow, a cause for regret for the past and projected by contemporaries on their own realities. They are also a cause to regret for the past and a reason to be projected by contemporaries on their own reality.

Piast concept is based on the concept of 'Sarmatism', which followed a pathway in accordance with political events and left

\footnotetext{
${ }^{16}$ Unger L. Europa, nie Azja. Gazeta Wyborcza. 2002. 4 lipca. S. 12.
} 
significant oriental traces on Polish civilization, bringing Christianity in 966. According to this approach, we can highlight incorporative and antiGerman idea of R. Dmowski ${ }^{17}$, who emphasizes that there is no place for a weak Poland between Russia and Germany. In addition, Poland also should own those lands where Polish people dominate ${ }^{18}$.

The second concept mentioned above, the Jagiellonian concept is based on memories of the Polish-Lithuanian Commonwealth, which emerged and became stronger under the Jagiellonians. Retracing the history, Polish state was established in the result of concluding successful unions and alliances, which eventually turned the Polish-Lithuanian Commonwealth into a multinational state that could have resisted encroachment by Russia ${ }^{19}$. The main emphasis in this foreign policy concept is placed by the Polish political elite on the special mission of Poland in the history of European civilization, as it has a divisive and at the same time unifying role between West and East. The most radical supporters of the Jagiellonian concept argued that the rights of Poland to the Russian lands and Lithuania arise from the merits of civilization ${ }^{20}$.

Created in the nineteenth century, the 'Jagiellonian myth' and the concept of 'civilizational mission of the Polish-Lithuanian Commonwealth in the East' received the second chance of representing Poland as a 'lawyer' of the former peoples of the Commonwealth, especially Ukraine, by integrating them into the European commonwealth.

One of the doctrines of the Jagiellonian concept is Prometheanism - a policy pursued by J. Piłsudski between the 20s and 30 s of the twentieth century. It resolved into the Renascence of Great Poland through the creation of a federation of Poland, Ukraine, Lithuania and Belarus. The Ukrainian Question played a decisive role in

${ }^{17}$ Wapinski R. Roman Dmowski. Lublin. : Wydawnictwo Lubelskie, 1989. S. 185.

${ }^{18}$ Roszkowski W. Najnowsza historia Polski (1914 - 1945). Warszawa: Świat książki, 2009. S. 29.

${ }^{19}$ Koniuszewski A. Meandry geopolityki. Wpływ gry mocarstw na położenie Polski. Warszawa, 2012. S. 94.

${ }^{20}$ Сінкевич С. Проблема цивілізаційної місії Речі Посполитої в історіографічному доробку представників краківської історичної школи. Наукові праџі МДГУ ім. П. Могили. Миколаїв, 2008. Т. 88. Вип. 75. С. 112-115. 
Prometheanism, because this was defined as an opportunity to deescalate Russia $^{21}$. J. Piłsudski was convinced that imperial Russia is the greatest threat on the way to the independence of Poland and other countries in the region, thus, it was in the interests of Poles, Lithuanians and Ukrainians to fight together for their independence.

Attempts to create a field of independent nation-states between Russia and the Second Polish-Lithuanian Commonwealth, linked with federal ties ${ }^{22}$, led to the problem of delimitation of territories. On all these lands Poles made up a significant part of the population and densely inhabited such territories as Eastern Galicia, Grodno and Vilnius region, although Ukrainians, Belarusians and Lithuanians dominated among the population $^{23}$.

The mentality of the Polish political elite was clearly manifested through the Endek doctrine incorporation, which was actively discussed in Poland aligned with Prometheanism. The incorporation doctrine provided for the unconditional inclusion in Poland of most of Lithuania, Belarus, and Ukraine (almost to the Dnieper) based on the borders of the Commonwealth in $1772^{24}$.

The Polish politician of the interwar period R. Dmowski defined the eastern Polish policy, and highlighted a thesis that being still powerful, but at the same time weakened, Russia had to give the part of its lands back to Poland. Similarly, Belarus and Ukraine had to be divided between Warsaw and Moscow on a national basis: lands, mostly populated by Poles, should have been annexed to Poland, and the rest - to Russia ${ }^{25}$.

In the same vein, the essential characteristic of Polish political elite's mentality of the interwar period was reduced to historically justified (from

${ }^{21}$ Суеля В. Юзеф Пілсудський. К.: Дух і Літера, 2018. С. 268-271.

22 Зашкільняк Л.О., Крикун М.Г. Історія Польщі: Від найдавніших часів до наших днів. Львів: Львівський національний університет імені Івана Франка, 2002. С. 451.

${ }^{23}$ Українсько-польські відносини. Новітня доба / [відп. ред. М. Литвин]: Національна академія наук України, Інститут українознавства ім.. І. Крип'якевича. Львів, 2017. C. $230-244$.

${ }^{24}$ Зашкільняк Л.О., Крикун М.Г. Історія Польщі: Від найдавніших часів до наших днів. Львів: Львівський національний університет імені Івана Франка, 2002. С. 451.

${ }^{25}$ Wapinski R. Roman Dmowski. Lublin: Wydawnictwo Lubelskie, 1989. S. 185. 
the Polish side) claims to Ukrainian ethnic lands, which had been identified in terms of civilizational understanding of history and vision of the Polish state perspectives. Accordingly, Ukrainians, unlike Poles, failed to create a nation-state, no counterbalance was offered by the Ukrainian side.

In 1945, in the aftermath of the war in Europe, the reality of foreign policy for both Poland and Ukraine was dictated by Moscow. In a broader perspective, in the period of construction of socialism, with its inherent totalitarian control and unification of public opinion, there is no pint in speaking about any political elites' mentality dimension in the context of bilateral relations. Discussions on the pages of the Parisian 'Culture' by Polish emigrants J. Giedroyc and J. Mieroszewski were the only exceptions.

Experts have seen this period as a noticeable mental shift with regard to the eastern policy of Poland and Ukraine among the representatives of the Polish political elite (only emigrants though). J. Giedroyc and J. Mieroszewski recognized the irreversibility of territorial changes because of the $\operatorname{war}^{26}$. In the 1950s and 1960s, this tended to be an innovative position contradicting the established popular visions of the Polish emigration politicians in Great Britain. To be more precise, Poland was supposed to agree to its post-war borders and abandon the ideas of revisionism. Literally, for nowadays, such a mental dimension of Ukraine in the Polish society is quite logical and obvious, but in the days of the Polish People's Republic, the vast majority of Polish political emigrants did not accept the existing borders, and recognized only the borders of the Second Polish Lithuanian Commonwealth.

The beginning of a new period in Poland's history can be marked on June 4, 1989, when "Solidarity" won the election and proposed a new Eastern policy called the 'two-vector policy', being implemented in 1990. On the one hand, it consisted of supporting the former Soviet republics aspiring to independence and, on the other hand - in maintaining contacts with the Soviet authorities without violating the

${ }^{26}$ Мєрошевський Ю. Російський «польський комплекс» і простір УЛБ. Простір свободи. Україна на шпальтах паризької «Культури» / Упор. Богуміла Бердиховська. К. : Критика, 2005. С. 195-209. 
Warsaw Pact. In short, it was a chance to implement the Prometheanism ideas while missing Moscow.

We believe that at this stage there were serious transformations of the mentality of the Polish political elite towards Ukraine and the vision of Polish-Ukrainian interstate relations. In the early 1990s, in the independent Ukrainian state, the state's mentality towards the bordering Republic of Poland began forming. The common desire for good neighbor relations was implemented by the end of the 1990s through a strategic partnership, and Poland's support for Ukraine during the Orange Revolution. It should be emphasized that it only strengthened mutual sympathy of both Ukrainian and Polish societies, as well as greatly cohering the mentalities of neighboring nations. However, shared historical legacy and associated historical memory continue to be dissonant in Ukrainian-Polish interstate and interethnic relations until present day.

\section{Historical memory as the psychological make-up of the nation}

A recent review of the literature on this found that nowadays there is hardly anyone on both sides of the Polish-Ukrainian border, who is unaware of the current discussions about shared historical memory by the Republic of Poland and Ukraine. The media of both countries are competing for disclosing the fact of mutual insults and claims regarding the interpretation of the historical past, the so-called "history wars", connected with the Volhynia tragedy, and strained Ukraine-Poland relations. In this context, it is worth paying attention to the warning of the American researcher T. Snyder, pointing out the impossibility of the rightness of one of the parties in such disputes ${ }^{27}$. Disputes as to whether these killings could be considered genocide continue to this day.

A clear trend of the memory transformations that have engulfed the Republic of Poland and Ukraine (and the whole Europe in general) at the end of the twentieth century became the return of the victimized

${ }^{27}$ Snyder T, Gdy na Ukrainie wojna, lepiej ws. zbrodni wołyńskiej oddzielić historię od polityki. URL: https://wiadomosci.dziennik.pl/opinie/artykuly/532748,snyder-gdy-na-ukrainiewojna-lepiej-ws-zbrodni-wolynskiej-oddzielic-historie-od-polityki.html 
groups from the backyards of memory that till that moment remained in the shadow of the official historiography. Precisely at the end of the twentieth century, the first steps were made to open archives in posttotalitarian countries. Memories of those who stayed silent until that moment gained the wide dissemination. The opened archival documents and testimonies of participants and eyewitnesses of the events that were concealed before were interpreted in the concept of filling so-called "white spots" in history. Back then, researchers imagined history, as well as historical memory, as a holistic picture that lacked individual puzzles. Therefore, it is worth erasing these 'white spots', but rather 'bloody spots' (including the entire twentieth century as the biggest amount of these 'spots'), filling them with information and thus eliminating them. Drawing on an extensive range of sources, the historical picture will be complete and clearer, and the national mentality will lose the taste of the bitterness of insults but quickly it became clear that the idea of 'white spots' as the concealed truth was too simplistic. It appears that the historical picture and maps compiled by neighbors are significantly different and it is not so easy for joint groups of historians to reduce the historical past to one denominator. At the same time, the academia clearly embraced that the so-called 'common historical denominator' not only explains the past but also more importantly, constructs the present and the future by adjusting the mentality of people ${ }^{28}$.

While analyzing the situation in Ukraine, we should note that the special complexity of historical memory formation in the national policy and with the further adjustment of national mentality has been lying in an aggravation of political sentiments polarization that is not always embedded in the regional dichotomy of 'East-West' ${ }^{29}$.

28 Набок С. Політика пам'яті у сучасній Україні: проблеми формування та контоверсійність наслідків. Етнополітичний контекст соиіокультурних трансформацій у сучасні Україні. Ред..кол. О. Рафальський, В. Войналович, Л. Нагорна. - Київ: ІПіЕНД ім.. І.Ф. Кураса НАН України, 2017. С. 233.

${ }^{29}$ Срільчук Л. Сучасний польський націоналізм і українсько-польські суперечності нові обличчя старих проблем. Історичні і політологічні дослідження. Науковий журнал. № 1 (64). Вінниця, 2019. С. 197. 
First underpinnings of the Ukrainian society's political drama can be traced during 15 years of its independence, since its political class failed to create a coherent 'Ukrainian memory project ${ }^{30}$. In addition, the recent study on various types of collective identity prove the political identity to be particularly vulnerable in the context of destabilization, which has become a visible sign of the Ukrainian life. The Ukrainian society, in fact, is deprived of unifying incentives - neither ideology, nor history, nor do commonalities of values play a crucial role. Only a clearcut and balanced policy of memory promoted by the state can change the state of affairs.

Laying a theoretical foundation for the 'politics of memory', in 1925, a French sociologist M. Halbwachs attempted to distinguish between the concepts of 'historical memory' and 'collective memory' in his book "The Social Frameworks of Memory" antagonistic, because the collective memory, formed artificially according to someone's group interests, inevitably accompanied by the destruction of historical memory, since it displaces the whole layers of history that are not aligned with the prevailing stereotypes in this society.

According to M. Halbwachs' arguments and conclusions, it should be noted that it is hardly possible to construct the concept of 'objective' historical memory on such a contradiction. After all, the range of people's own life experience limits an individual's natural, reminiscencebased memory. In addition, what is embedded in the concept of 'historical memory' at the household level is the same artificial construction as a collective memory.

According to the Ukrainian historian Y. Shapoval, in contrast to memory as such, historical memory is 'genetically' programmed to evaluate and is inextricably linked to the mentality. Historical memory is not only characterized by recollection and reproduction, but also by a

${ }^{30}$ Етнополітичний контекст соціокультурних трансформацій у сучасні Україні / Ред..кол. О. Рафальський, В. Войналович, Л. Нагорна. Київ: ІПіЕНД ім. І.Ф. Кураса НА України, 2017. С. 21.

31 Гельбвакс М. Социальные рамки памяти. Пер. с фр. и вступ. статья С. Н. Зенкина М.: Новое издательство, 2007. С. 48. 
peculiar perception or non-perception, approval or condemnation. Every historical fact allegedly falls under the spotlight and becomes the object of meticulous analysis. In addition, a biased individual usually carries out such analysis. Guided by their own system of values, the people themselves choose a 'starting point' in the approach to the era they are investigating. Nevertheless, the almost inevitable 'evaluation binary' (white and black, good and evil) prevents from seeing the halftones and nuances, the pros and cons, and vice versa can be changed surprisingly easy. This opens up almost unlimited opportunities for manipulating the public consciousness ${ }^{32}$.

In our case study, an in-depth analysis of the up-to-date situation in Ukraine on issues concerning the formation of historical memory shows the permanent politicization of the problem. The reason for this, in our opinion, lies in both objective and subjective factors. In particular, decommunization processes and the development of an independent Ukrainian state caused a natural change in the people's assessments of the historical legacy, in reality, is an objective regularity ${ }^{33}$. Subjective factors include a different interpretation of the past by different political and social groups, the inclusion of historical themes in the context of the political promises of individuals and political parties, etc.

The present study was designed to determine the effect of important aspects of Ukraine's historical past assessment that has outgrown not only the scope of scientific discussions, but also went beyond the borders of two states, which is manifested in the interpreting history to politically manipulate by the public opinion, particularly in Poland. Collective ideas about the past acquire a valued and, at the same time, semantic dimension exclusively in the social context and are determined by the 'social framework'. Communities reconstruct the past for the needs of the present. Changes in the socio-political context

32 Шаповал Ю. Політика пам'яті в сучасній Україні. URL: http://khpg.org/ index.php?id=1230112797

33 Добржанський О. Проблеми опіки над місцями національної пам'яті в українсько-польських відносинах. Sprawy Międzynarodowe. Warszawa. 2018. T.L XXI. Numer 1. S. 245- 251. 
inevitably lead to a full change of the collective memory and national mentality ${ }^{34}$.

The Republic of Poland was the first to break with the communist past and step onto the path of revising its own historical policy. Thus, there was a process of official revision of its own historical policy towards its eastern neighbors in post-communist Poland, especially to Ukraine. As early as August 3, 1990, the Senate of the Republic of Poland issued a Resolution condemning the 1947 Vistula action ${ }^{35}$. The document stated that the communist authorities were responsible for the mass displacement of Ukrainians. By this decision, the Senate actually recognized the partial responsibility of the Polish side for the action organized by the regime of Boleslaw Berut, and demonstrated its attitude to the Vistula tragedy ${ }^{36}$.

The next steps taken by official Warsaw in terms of rapprochement with Ukraine were good-neighborly and impartial and they became the first to harmonize the bilateral relations. Thus, on July 28, 1990, the Sejm of the Republic of Poland approved the Resolution, facilitating the adoption of the Declaration of State Sovereignty by the Verkhovna Rada of the Ukrainian SSR as an expression of Ukraine's strivings for its independence ${ }^{37}$. The Polish Sejm approved the next Resolution on Ukraine on August 31, 1991. The document welcomed the Act of Independence of Ukraine, "Poland, which puts the freedom and independence of its own state as a top priority, fully understands and realizes the significance of the historic decision of the Ukrainian

34 «Концептуальні засади державної політики пам'яті». Аналітична записка.. Національний інститут стратегічних досліджень. URL: http://www.niss.gov.ua/articles/269

35 Стрільчук Л. Нінічук А. Війна пам'яті та війни пам'ятників у сучасних українсько-польських відносинах. Луцьк: Вежа-Друк, 2019. С. 53.

${ }^{36}$ Хахула Л. Україна та українці в офіційному та медійному дискурсах сучасної Польщі (перша половина 1990-х років). Україна-Польщ̧а: історична спадщина і суспільна свідомість. 2010-2011. Вип. 3-4. С. 224.

${ }^{37}$ Monitor Polski. 1990. Nr 30. Poz. 234. 
Parliament..., ${ }^{38}$. The Republic of Poland became the first state to recognize Ukraine's independence on December 2, $1991^{39}$.

Further steps towards the official development of Poland-Ukraine cooperation were manifested in the 'Treatise on Good Neighborhood, Friendly Relations and Cooperation' signed during the visit of the President of Ukraine L. Kravchuk to Poland in May 1992. Additionally, this document stipulated the rights of national minorities on preservation and development of cultural, linguistic, religious identities and principles for the care of existing and found in the future military and civilian graves ${ }^{40}$.

The unarticulated national policy of historical memory started its shaping from the moment of the USSR's collapse and the rise of independent Ukraine. Traditionally, this sector of public administration in Ukraine was controlled directly by the then presidents and, therefore, depended on their experience. With minor differences, by 2005 the policy of historical memories was pursued on a consistent basis but still characterized by amorphousness, ambivalence, and was of a conjuncture nature, held in the general flow of compromises to reconcile public opinion between the followers of post-Soviet and state narratives. Namely, the country's political leaders did not vigorously attempt to shape the citizens' historical consciousness but to adapt historical policy to situational circumstances ${ }^{41}$.

Of particular importance of our study are the events happening at the turn of the 90s of the twentieth century and early twenty-first century in both Ukraine and the Republic of Poland. They marked a new round of bilateral relations, after both states' gaining independence, almost simultaneously, and established in the international arena as full participants in interstate relations, there is a convergence of their foreign policy vectors, a mutually beneficial business partnership, and economic

${ }^{38}$ Monitor Polski. 1991. Nr 29. Poz. 205.

${ }^{39}$ Стрільчук Л. В. Україна - Польща: від добросусідських відносин до стратегічного партнерства (кінець XX - початок XXI століття). Луцьк: Волинські старожитності, 2013. C. 143-145.

${ }^{40}$ Dziennik Ustaw RP. 1993. Nr 125. Poz. 573.

${ }^{41}$ Стрільчук Л. Нінічук А. Війна пам'яті та війни пам'ятників у сучасних українсько-польських відносинах. Луцьк: Вежа-Друк, 2019. С. 55. 
reforms. The outcome of political interaction between the Presidents' neighboring states was the establishment of Ukraine-Poland relations as strategic partners, which was finally formed in the late $90 \mathrm{~s}$ of the twentieth century (tandem A. Kwaśniewski - L. Kuchma) ${ }^{42}$, that testifies to coordinated and coherent policy of memory, represented by the Presidents of both states.

Several reports have shown that a qualitatively new stage in the implementation of historical memory policy in Ukraine and its representation abroad began in 2005. It is associated with the President of Ukraine Viktor Yushchenko. Since then, the state policy of historical memory, its essence and methods have undergone radical changes. The principled position and determination of actions in the formation of collective ideas about the past were one of the main reasons for the escalation of domestic and foreign policy controversy over issues of historical memory ${ }^{43}$.

Several lines of evidence suggest that according to Y. Shapoval, throughout a couple of centuries nation-states have been engaged in constructing a 'collective memory' with greater or lesser success. Simultaneously, the general tendency was immanently established in historiography as a political bias: the reduction to the absolute of its exceptional merits was accompanied by outdated claims to 'others'. Accordingly, the politics of memory is a process of staying in tune with collective outlook epitomizing the mood of the era, and mentally understandable and justified images of the past. Importantly, the mediasymbolic sphere, where 'battle for the past' occurs as a clash of interests of various social strata and political actors. Because the modeled past is in some way a valuable symbolic resource and has its own mobilizing potential, its interpretations in polarized societies are gaining the power of ideological weapons. At the same time, they are able to perform the

42 Нінічук А.В. Концепт історичної пам'яті як чинник ускладнення українськопольських взаємин. VI Всеукраӥнські політологічні читаття імені професора Богдана Яроша : зб.наук.пр. Луцьк: Вежа-Друк, 2017. С. 77.

${ }^{43}$ Стрільчук Л., Нінічук А. Війна пам'яті та війни пам'ятників у сучасних українсько-польських відносинах. Луцьк: Вежа-Друк, 2019. С. 56. 
functions of social protection, to minimize the traumatic impact of current realities ${ }^{44}$.

The danger of rewriting history for political purposes is obvious. Polish researcher E. Jedlitsky identifies two options when historical memory enables achieving maximum tension and confrontation in a society: 1) consecration of some historical events that would turn them into influential symbols and myths; 2) a reminder of mass offenses through the fault of another group or force. The researcher argues that collective memory can be 'cold' versus 'hot', in case 'cold' stores facts, then 'hot' produces a politically relevant version of the past, and further developments will depend on the emotional tension in society ${ }^{45}$. Addressing the heroic and 'victorious' history and the lack of responsibility for the insults inflicted on other societies shape the socalled memory of the war. For example, the theorization in Ukraine of the UPA, S. Bandera, and at the same time the adoption in July 2016 by the Sejm of the Republic of Poland of the resolution 'On July 11 as the Day of Remembrance of Poles, victims of genocide committed by the OUN-UPA'. This problem has received substantial interest, since the Sejm approved forgetting and erasing all scholars and political elites' achievements of the two countries from a quarter century history and demonstrated diametrically different, irreconcilable approaches to the formation of memory policy in Ukraine and Poland.

Thus, the politics of memory is the process of building images of the past in tune with the moods of the era (and certain political forces). It is in this information-symbolic sphere that the 'battle for the past' takes place with a sharp clash of interests of various social strata and political actors. Because in some way the modeled past is a valuable symbolic resource and has its own mobilizing potential, its interpretations in polarized societies

${ }^{44}$ Шаповал Ю. Політика пам'яті в сучасній Україні / Ю. Шаповал // Політика і права людини. URL: http://khpg.org/index.php?id=1230112797

45 Добржанський О. Вплив сучасних ЗМІ на формування історичної пам'яті українців та поляків. Історичні $i$ політологічні дослідження. Науковий журнал. Спечіальний випуск: доповіді на міжнародній науково-практичній конференціі «Трансформачії історичної пам'яті». Вінниця, 2018. С. 18-20. 
are gaining the power of ideological weapons and are able to significantly adjust the mentality. At the same time, they are able to perform the functions of social protection, to minimize the traumatic impact of modern realities. In other words, the historical memory of a people is a reflection of its mental face. Given the historical experience of the neighborhood of Ukrainians and Poles, we can say about the direct dependence of historical memory and the mental dimension of interethnic relations.

\section{CONCLUSIONS}

Therefore, the purpose of the research is to theoretically prove and develop on the problem of mentality and different perceptions of a Ukraine-Poland cross-border reality. The initiation process and development of the mentality of both Poles and Ukrainians, while having a long evolutionary-progressive character, acts as a priority feature of the establishment of the cultural-historical and genetic code of civilization. The psychological make-up of Polish and Ukrainian civilization has been formed historically with all of their strengths and weaknesses. They distinguish and emphasize Poland and Ukraine from other regional civilizations and there is not only the past eternalized, but also a powerful projection on the future. The mental dimension of Polish-Ukrainian relations should be a focal point in further building of interstate and interethnic relations between Ukrainians and Poles.

To summarize, it is necessary to emphasize that the mentality is an integral part of human society, its history, culture, morality that distinguish a nation. The mentality also can be defined as a certain level of religious, economic, cultural and political development of the society (in this case, Polish and Ukrainian). Consequently, the mentality assimilates everything socially valuable related to the history, customs, morals and religion, and, at the same time, serves as a valuable asset to the world culture and civilization. In recent decades, we have witnessed the extent to which the national mentality and national historical memory, as its derivative, influence and define interethnic PolishUkrainian relations. 
It is widely thought that in recent years, the national mentality is gaining considerable independence from Polish and Ukrainian societies and has the opport unity to considerably affect them. There is increasing awareness that memory is embedded in social context and subject to social influence, and little connected with theoretical integration of memory and social psychological thinking. Various approaches have been proposed to solve the issue of mentalities in the context of modern Poland-Ukraine relations. The problem under study has become a vital issue for future research on encouraging the Ukraine-Poland authorities, academia and public to follow a multiperspective approach to investigating neighboring countries' history that allows a shared vision of their past in order to promote social cohesion, peace and democracy, whilst cohering their mentality.

\section{SUMMARY}

Theoretical and conceptual frameworks for a collective mentality are recognized as being an indispensable part of the research of a human society, its history, culture, morality, the trait that distinguishes the nation and unites a man and a society, between the nation and power and as a necessary stabilizing factor in the social system. Thus, a growing body of evidence speaks for Ukraine-Poland relations, providing a great boost to their ongoing political confidence-building narrative as an indispensable part of cross-border cooperation strategies for their sustainable development. This research paper provides an insight of that field by sketching out the major themes that exist in the body of scholarship known as the peculiarities of mentality setting and the moral landscape of two nations that immediately influence different interpretations of the shared historical memory and the experience of interaction between the two nations in the neighboring countries.

Therefore, the authors' focus revolves around the essential characteristics of similar mentality and perception of contemporary Ukraine-Poland relations. Furthermore, the problems of mentality and mind setting have attracted much attention in the field of modern 
humanities studies, which pivotal focus is a holistic system of knowledge about human society, culture, environment and history.

\section{REFERENCES}

1. Beck, J. Pradier, E. 2011: Governance in der transnationalen Regionalpolitik: Bestandsaufnahme und Perspektiven der Kooperationsbeziehungen in grenzüberschreitenden Verflechtungsräumen, in: Joachim Beck / Birte Wassenberg (Hrsg), Grenzüberschreitende Zusammenarbeit erforschen und leben (Band 2): Governance in Deutschen Grenzregionen Stuttgart (Steiner), S. 107-135.

2. Стрільчук Л. Історична пам'ять українців та поляків: пошук шляхів примирення чи привід до конфлікту? Історичні та політологічні дослідження. Науковий журнал. Спеціальний випуск: доповіді на міжнародній науково-практичній конференцій «Трансформації історичної пам'яті». Вінниця, 2018. С. 176-183.

3. Михальченко Н. Великий цивилизационный взрыв на рубеже XX - XXI векав. К.: Парламентское издательство, 2016. С. 3-5.

4. Калакура Я. Ментальний вимір української цивілізації. Київ: Генеза. 2017.

5. Рафальський О. Україна як цивілізаційний феномен. К.: Бланк-Прес, 2010.

6. Горєлов М., Моця О., Рафальський О. Українська етнічна нація. К.: Еко-продакшин, 2012.

7. Попович М. Українська національна ментальність. Проблеми теорії ментальності. Відп.ред. М.В. Попович. К.: Наукова думка, 2006. С. 232-240.

8. Стрільчук Л., Стрільчук В. Інституційні складові українсько-польських гуманітарних взаємин i співробітництва. Монографія. Луцьк: Волинські старожитності, 2013.

9. Strilchuk L. The Ukrainian-Polish Confrontation in Volhynia in the Second World War: Historical Memory Transformations. Codrul Cosminului, 2018, Vol. XXIV, No. 1, P. 145-165. 
10. Заброварний С. До повного примирення i щирого порозуміння. Політика і час. 1997. № 9. С. 5-11.

11. Добржанський О. Еволюція суспільно-історичних стереотипів у свідомості українців та поляків на прикладі опіки над місцями національної пам'яті. Україна-Польща: історичне сусідство. Матеріали міжнародної наукової конферениії 19-20 травня 2017 р. Вінниця: ТОВ «Нілан-ЛТД», 2017. С. 365-370.

12. Стрільчук Л. Проблеми історичної пам'яті в сучасних українсько-польських взаєминах. Украӥна-Польща: історичне сусідство. Матеріали міжнародної наукової конферениії 19-20 травня 2017 р. Вінниця, 2017. С. 373-378.

13. Unger L. Europa, nie Azja. Gazeta Wyborcza. 2002. 4 lipca. S. 12.

14. Wapinski R. Roman Dmowski. Lublin. : Wydawnictwo Lubelskie, 1989.

15. Roszkowski W. Najnowsza historia Polski (1914-1945). Warszawa: Świat książki, 2009.

16. Koniuszewski A. Meandry geopolityki. Wpływ gry mocarstw na położenie Polski. Warszawa, 2012.

17. Сінкевич Є. Проблема цивілізаційної місії Речі Посполитої в історіографічному доробку представників краківської історичної школи. Наукові праці МДГУ ім. П. Могили. Миколаїв, 2008. Т. 88. Вип. 75. С. 112-115.

18. Суеля В. Юзеф Пілсудський. К.: Дух і Літера, 2018.

19. Зашкільняк Л.О., Крикун М.Г. Історія Польщі: Від найдавніших часів до наших днів. Львів: Львівський національний університет імені Івана Франка, 2002.

20. Українсько-польські відносини. Новітня доба / [відп. ред. М. Литвин]: Національна академія наук України, Інститут українознавства ім. І. Крип'якевича. Львів, 2017.

21. Мєрошевський Ю. Російський «польський комплекс» $\mathrm{i}$ простір УЛБ. Простір свободи. Украӥна на шпальтах паризької 
«Культури»/ Упор. Богуміла Бердиховська. К.: Критика, 2005. C. 195-209.

22. Snyder T, Gdy na Ukrainie wojna, lepiej ws. zbrodni wołyńskiej oddzielić historię od polityki. URL: https://wiadomosci.dziennik.pl/ opinie/artykuly/532748,snyder-gdy-na-ukrainie-wojna-lepiej-ws-zbrodniwolynskiej-oddzielic-historie-od-polityki.html

23. Набок С. Політика пам'яті у сучасній Україні: проблеми формування та контоверсійність наслідків. Етнополітичний контекст соиіокультурних трансформацій у сучасні Украйні. Ред. кол. О. Рафальський, В. Войналович, Л. Нагорна. - Кийв: ІПіЕНД ім. І.Ф. Кураса НАН України, 2017. С. 229-283.

24. Срільчук Л. Сучасний польський націоналізм i українсько-польські суперечності - нові обличчя старих проблем. Історичні і політологічні дослідження. Науковий журнал. № 1 (64). Вінниця, 2019. С. 192-200.

25. Етнополітичний контекст соціокультурних трансформацій у сучасні Україні / Ред..кол. О. Рафальський, В. Войналович, Л. Нагорна. Київ: ІПіЕНД ім. І.Ф. Кураса НА України, 2017.

26. Гельбвакс М. Социальные рамки памяти. Пер. с фр. и вступ. статья С. Н. Зенкина М.: Новое издательство, 2007.

27. Шаповал Ю. Політика пам'яті в сучасній Україні. URL: http://khpg.org/index.php?id=1230112797

28. Добржанський O. Проблеми опіки над місцями національної пам'яті в українсько-польських відносинах. Sprawy Międzynarodowe. Warszawa. 2018. T. LXXI. Numer 1. S. 245-251.

29. «Концептуальні засади державної політики пам'яті». Аналітична записка.. Національний інститут стратегічних досліджень. URL: http://www.niss.gov.ua/articles/269

30. Стрільчук Л. Нінічук А. Війна пам'яті та війни пам'ятників у сучасних українсько-польських відносинах. Луцьк: Вежа-Друк, 2019.

31. Хахула Л. Україна та українці в офіційному та медійному дискурсах сучасної Польщі (перша половина 1990-х років). Україна- 
Польща: історична спадщина і суспільна свідомість. 2010-2011. Вип. 3-4. С. 222-233.

32. Monitor Polski. 1990. Nr. 30. Poz. 234.

33. Monitor Polski. 1991. Nr. 29. Poz. 205.

34. Стрільчук Л. В. Україна - Польща: від добросусідських відносин до стратегічного партнерства (кінець XX - початок XXI століття). Луцьк: Волинські старожитності, 2013.

35. Dziennik Ustaw RP. 1993. Nr. 125. Poz. 573.

36. Нінічук А.В. Концепт історичної пам'яті як чинник ускладнення українсько-польських взаємин. VI Всеукраӥнські політологічні читаття імені професора Богдана Яроша : зб.наук.пр. Луцьк: Вежа-Друк, 2017. С. 77-80.

37. Добржанський О. Вплив сучасних ЗМІ на формування історичної пам'яті українців та поляків. Історичні і політологічні дослідження. Науковий журнал. Спеиіальний випуск: доповіді на міжнародній науково-практичній конференції «Трансформації історичної пам'яті». Вінниця, 2018. С. 16-22.

\section{Information about the authors: Strilchuk L. V.,}

Doctor of Historical Science, Professor, Head of the Department of World History and Philosophy, Lesia Ukrainka Eastern European National University 13, Voli Avenue, Lutsk, 43025, Ukraine

Dobrzhanskiy O. V.,

Doctor of Historical Science, Professor, Dean of the Faculty of History, Political Science and International Studies Yuriy Fedkovych Chernivtsi National University 2, Kotsyubynsky, Chernivtsi, 58012, Ukraine 